Autor:

Eunice Fumagalli Martins e Scheer

Título:

\title{
Transferência de tecnologia
}

Banca Examinadora:

Presidente: Dr. Alfredo de Assis Gonçalves Neto

Dr. Altino Portugal Soares Pereira

Dr. Aloisio Surgik

Defesa: $\quad 11$ de agosto de 1992.

\section{Resumo}

O presente estudo, abstendo-se das questões que excedem o marco do Direito Privado, tem por objeto exatamente o tratamento conferido pelo Direito às transferências de tecnologia que envolvem sujeitos de países em desenvolvimento, como o Brasil. Nessa linha, enfoca os mecanismos adotados pelas legislações nacionais e, especialmente a brasileira, para neutralizar ou amenizar os efeitos do desequilíbrio de poder entre os produtores e os dependentes de tecnologia. Embora não se ignore as operações de circulação interna de tecnologia, tampouco os contratos de exportação, cujo volume é bastante reduzido, maior distinção é dada às operações de importação de tecnologia que, em verdade, representam a maior parte das relações jurídicas nessa área, bem como mais detalhado tratamento pelas legislações nacionais dos países em desenvolvimento. 